\title{
Airborne observations and modeling of springtime stratosphere-to-troposphere transport over California
}

\author{
E. L. Yates ${ }^{1}$, L. T. Iraci ${ }^{1}$, M. C. Roby ${ }^{2}$, R. B. Pierce ${ }^{3}$, M. S. Johnson ${ }^{4}$, P. J. Reddy ${ }^{5}$, J. M. Tadić ${ }^{1, *}$, M. Loewenstein ${ }^{1}$, \\ and W. Gore ${ }^{1}$ \\ ${ }^{1}$ Atmospheric Science Branch, NASA Ames Research Center, Moffett Field, CA 94035, USA \\ ${ }^{2}$ Department of Meteorology, San Jose State University, San Jose, CA 95192-0104, USA \\ ${ }^{3}$ NOAA/NESDIS Advanced Satellite Products Branch Madison, WI 53706, USA \\ ${ }^{4}$ Biospheric Science Branch, NASA Ames Research Center, Moffett Field, CA 94035, USA \\ ${ }^{5}$ Air Pollution Control Division, Colorado Department of Public Health \& Environment, Denver, CO 80246, USA \\ *now at: Department of Global Ecology, Carnegie Institution for Science, Stanford, CA 94305, USA
}

Correspondence to: E. L. Yates (emma.1.yates@nasa.gov)

Received: 6 March 2013 - Published in Atmos. Chem. Phys. Discuss.: 18 April 2013

Revised: 22 November 2013 - Accepted: 23 November 2013 - Published: 20 December 2013

\begin{abstract}
Stratosphere-to-troposphere transport (STT) results in air masses of stratospheric origin intruding into the free troposphere. Once in the free troposphere, ozone $\left(\mathrm{O}_{3}\right)$ rich stratospheric air can be transported and mixed with tropospheric air masses, contributing to the tropospheric $\mathrm{O}_{3}$ budget. Evidence of STT can be identified based on the differences in the trace gas composition of the two regions. Because $\mathrm{O}_{3}$ is present in such large quantities in the stratosphere compared to the troposphere, it is frequently used as a tracer for STT events.

This work reports on airborne in situ measurements of $\mathrm{O}_{3}$ and other trace gases during two STT events observed over California, USA. The first, on 14 May 2012, was associated with a cutoff low, and the second, on 5 June 2012, occurred during a post-trough, building ridge event. In each STT event, airborne measurements identified high $\mathrm{O}_{3}$ within the stratospheric intrusion, which were observed as low as $3 \mathrm{~km}$ above sea level. During both events the stratospheric air mass was characterized by elevated $\mathrm{O}_{3}$ mixing ratios and reduced carbon dioxide $\left(\mathrm{CO}_{2}\right)$ and water vapor. The reproducible observation of reduced $\mathrm{CO}_{2}$ within the stratospheric air mass supports the use of non-conventional tracers as an additional method for detecting STT. A detailed meteorological analysis of each STT event is presented, and observations are interpreted with the Realtime Air Quality Modeling System (RAQMS). The implications of the two STT events are
\end{abstract}

discussed in terms of the impact on the total tropospheric $\mathrm{O}_{3}$ budget and the impact on air quality and policy-making.

\section{Introduction}

Transport of stratospheric air into the troposphere, referred to as stratosphere-to-troposphere transport (STT), contributes to and alters the trace gas composition of the troposphere, and as such STT has been extensively studied for over $50 \mathrm{yr}$ (e.g., Danielsen, 1968; Danielsen and Mohnen, 1977; Lamarque and Hess, 1994; Sprenger et al., 2003; Thompson et al., 2007; Lefohn et al., 2011). Ozone $\left(\mathrm{O}_{3}\right)$ is present in large quantities in the stratosphere compared to the troposphere and is commonly used as a tracer for STT. In the free troposphere, air masses of stratospheric origin can be transported and mixed with tropospheric air masses, typically forming filamentary structures, which appear as $\mathrm{O}_{3}$ laminae in $\mathrm{O}_{3}$ profiles detected by ozonesondes, in situ aircraft measurements and $\mathrm{O}_{3}$ lidar (Zanis et al., 2003; Cooper et al., 2005; Trickl et al., 2011; Langford et al., 2012). Understanding the dynamic processes that control the tropospheric $\mathrm{O}_{3}$ budget is of importance not only for understanding surface air quality in areas affected by STT, but also because upper tropospheric $\mathrm{O}_{3}$ is an important greenhouse gas affecting outgoing longwave radiation (Worden et al., 2008) and impacting surface temperature (IPCC, 2007). 
STT events are episodic in nature and vary considerably with latitude and season. In western North America (the end of the Pacific storm track) peak STT occurs during the late winter to late spring (e.g., Sprenger et al., 2003; Stohl et al., 2003; Skerlak et al., 2013), when synoptic-scale and mesoscale processes (e.g., tropopause folds in the vicinity of the polar and subpolar jets, cutoff lows, mesoscale convective complexes) facilitate the tropopause to fold, allowing for stratospheric air masses to be transported downward to the troposphere. Tropopause folds and cutoff lows, which emphasize the vertical structure (former) and horizontal structure (latter) in which a stratospheric intrusion can occur (Stohl et al., 2003), have been identified as the most important mechanisms to cause STT and have subsequently been the focus of STT investigations (e.g., Danielsen and Mohnen, 1977; Ebel, 1991; Vaughan et al., 1994; Bonasoni, et al., 2000; Søensen and Nielson, 2001; Lefohn et al., 2011). The frequency and magnitude of STT events are important factors in understanding the possible degree to which they affect surface and free troposphere $\mathrm{O}_{3}$ mixing ratios (Lefohn et al., 2011).

The stratosphere and troposphere are separated by the tropopause. Traditionally the tropopause is defined by the "thermal tropopause", which is the lowest level at which the temperature lapse rate decreases to $2 \mathrm{~K} \mathrm{~km}^{-1}$ or less and the averaged lapse rate between this level and any level within $2 \mathrm{~km}$ does not exceed $2 \mathrm{~K} \mathrm{~km}^{-1}$ (WMO, 1986). In the extratropics the tropopause corresponds well with a surface of constant potential vorticity (PV), allowing for a "dynamical tropopause" definition. Tropopause PV values in literature range from 1.6 to 3.5 potential vorticity units (PVU) with 2 PVU used most often (Stohl et al., 2003). Both of these tropopause definitions are routinely used in forecasting and modeling STT events (e.g., Sprenger et al., 2003; Stohl et al., 2003).

Observations of STT have been reported in long-term data sets from mountain-top $\mathrm{O}_{3}$ sites measuring the free troposphere (e.g., Bonasoni et al., 2000; Stohl et al., 2000) and from $\mathrm{O}_{3}$ profiles measured by aircraft, ozonesondes and $\mathrm{O}_{3}$ lidar (e.g., Zanis et al., 2003; Cooper et al., 2005; Bowman et al., 2007; Bourqui and Trepainer, 2010; Langford et al., 2012). Identifying STT within the tropospheric boundary layer, especially at near-sea-level surface sites, is challenging. The stratospheric characteristics (high $\mathrm{O}_{3}$, low humidity, high PV) may be lost by the time this air is entrained into the boundary layer, making STT difficult to diagnose and forecast. In addition, the $\mathrm{O}_{3}$ mixing ratio within STT events is expected to be highly variable depending on the stratospheric origin and degree of mixing in the free troposphere. Although evidence of STT at sea-level surface sites has been presented (Chung and Dann, 1985; Langford et al., 2012; Lefohn et al., 2012; Lin et al., 2012), the magnitude of the effects of STT on boundary layer $\mathrm{O}_{3}$ mixing ratios is still under debate (Fiore et al., 2003; Langford et al., 2009; Lefohn et al., 2011; Lin et al., 2012).
The United States Environmental Protection Agency (EPA) sets National Ambient Air Quality Standards (NAAQS) for ground-level $\mathrm{O}_{3}$, which are used to assess air quality. The $2008 \mathrm{NAAQS}$ for $\mathrm{O}_{3}$ require that the $3 \mathrm{yr}$ average of the annual fourth-highest daily maximum $8 \mathrm{~h}$ mean mixing ratio be less than or equal to $75 \mathrm{ppbv}$ (parts per billion by volume) (US EPA, 2006), with a decision on the proposed reduction of the NAAQS $\mathrm{O}_{3}$ target to $60-70$ ppbv due in 2014 (US EPA, 2010). The formulation of the NAAQS $\mathrm{O}_{3}$ standard relies on the accurate identification of a representative background mixing ratio of $\mathrm{O}_{3}$ that would occur in the United States in the absence of anthropogenic contributions. Current background $\mathrm{O}_{3}$ mixing ratios are estimated to be in the range of 15-35 ppbv (Fiore et al., 2003), contributing up to $47 \%$ towards the current NAAQS $\mathrm{O}_{3}$ target of 75 ppbv. Some studies have reported higher background $\mathrm{O}_{3}$ mixing ratios, particularly in springtime, suggesting that STT has a significant influence on the background $\mathrm{O}_{3}$ mixing ratios (Cooper et al., 2005; Hocking et al., 2007; Lefohn et al., 2011; Langford et al., 2012, Lin et al., 2012). If the proposed reduction of NAAQS $\mathrm{O}_{3}$ target is approved, the identification of STT and evidence of its contribution towards background $\mathrm{O}_{3}$ mixing ratios will become increasingly important, as the gap between background $\mathrm{O}_{3}$ and the NAAQS $\mathrm{O}_{3}$ target is reduced.

The western United States, due to its location at the end of the North Pacific mid-latitude storm track, has been identified as a preferred location for deep STT reaching below 700 mbar (Sprenger and Wernli, 2003). Understanding the boundary conditions coming into the western United States is important for air quality issues. However large areas in the western United States have limited or no $\mathrm{O}_{3}$ data. In addition, the existing positive vertical gradient for $\mathrm{O}_{3}$, complex mountainous terrain of the western United States and resulting mesoscale dynamics further complicate efforts to model $\mathrm{O}_{3}$ concentrations.

In this paper, a detailed analysis of two STT events occurring during spring 2012 over California, USA, is presented. This work reports airborne in situ measurements of $\mathrm{O}_{3}$ and other trace gases, providing supporting evidence towards of the use of a non-traditional stratospheric tracer (carbon dioxide, $\mathrm{CO}_{2}$ ), which can be used in conjunction with $\mathrm{O}_{3}$ to help identify and interpret STT. In support of the observations and the case for STT, the following evidence is provided: analyses of the meteorological situations and an evaluation of Realtime Air Quality Modeling System (RAQMS) used to forecast and interpret observations. Finally a discussion of the implications of the two events on air quality and policymaking is also presented. 


\section{Experimental approach}

\subsection{Airborne instrumentation}

In situ measurements of $\mathrm{O}_{3}$ vertical profiles were carried out on board the Alpha Jet research aircraft as part of the Alpha Jet Atmospheric eXperiment (AJAX). The aircraft is based at and operated from NASA Ames Research Center at Moffett Field, CA $\left(37.415^{\circ} \mathrm{N}, 122.050^{\circ} \mathrm{W}\right)$. Scientific instrumentation is housed within one of two externally mounted wing pods, each of which has a maximum payload weight of $136 \mathrm{~kg}$. The aircraft was flown with one instrumented wing pod attached, containing an $\mathrm{O}_{3}$ monitor (described below) and a $\mathrm{CO}_{2}$ analyzer (Picarro Inc., model G2301-m), modified for flight installation The aircraft also carries GPS and inertial navigation systems that provide altitude, temperature and position information time-stamped with coordinated universal time (UTC) for each research flight.

Measurements of $\mathrm{O}_{3}$ mixing ratios were performed using a commercial $\mathrm{O}_{3}$ monitor (2B Technologies Inc., model 205) based on ultraviolet (UV) absorption techniques and modified for flight worthiness. The dual-beam instrument uses two detection cells to measure simultaneously the UV light intensity differences between $\mathrm{O}_{3}$-scrubbed air and un-scrubbed air to give precise measurements of $\mathrm{O}_{3}$. The monitor has been modified by upgrading the pressure sensor and pump to allow measurements at high altitudes, including a lamp heater to improve the stability of the UV source, and the addition of heaters, temperature controllers and vibration isolators to control the monitor's physical environment.

The air intake is through Teflon tubing (perfluoroalkoxy polymer, PFA) with a backward-facing inlet positioned on the underside of the instrument wing pod. Air is delivered through a $5 \mu \mathrm{m}$ PTFE (polytetrafluoroethylene) membrane filter to remove fine particles prior to analysis.

The $\mathrm{O}_{3}$ monitor has undergone thorough instrument testing in the laboratory to determine the precision, linearity and overall accuracy. Eight-point calibration tests (ranging from 0 to $300 \mathrm{ppbv}$ ) were performed before and after each flight using an $\mathrm{O}_{3}$ calibration source (2B Technologies, model 306 referenced to the WMO scale). Calibration settings for the $\mathrm{O}_{3}$ monitor were left at manufacturer default settings, and corrections to account for linearity offset and zero offset were applied during data processing. For the flights reported here, the linearity offset was determined to be 1.01 and the zero offset was -2.4 ppbv.

Calibrations in a pressure- and temperature-controlled environmental chamber were performed using the $\mathrm{O}_{3}$ calibration source over the pressure range $200-800 \mathrm{mbar}$ and temperature range -15 to $+25^{\circ} \mathrm{C}$, typical pressure and temperature ranges observed in the wing-mounted instrument pod during flight. Precision during chamber tests, determined from the standard deviation of $\mathrm{O}_{3}$ measurements taken every $10 \mathrm{~s}$, when sampling $\mathrm{O}_{3}$ mixing ratios of $50 \mathrm{ppbv}$ over $2 \mathrm{~min}$ duration and during simulated descent profiles, was found to be 2 ppbv. The zero offset, observed when sampling $\mathrm{O}_{3}$ scrubbed air during simulated descent profiles, was found to increase linearly by $0.6 \mathrm{ppbv}$ with decreasing chamber pressure (typical zero offset of $-2.4 \mathrm{ppbv}$ at ground level and $-3 \mathrm{ppbv}$ at $200 \mathrm{mbar}$ ). Instrument drift estimated based on $1 \mathrm{~h}$ of sampling $50 \mathrm{ppbv} \mathrm{O}_{3}$ was $1.5 \mathrm{ppbv}$. Overall uncertainty of the airborne $\mathrm{O}_{3}$ measurements is estimated to be $3.0 \mathrm{ppbv}$.

In situ $\mathrm{O}_{3}$ measurements, taken every $10 \mathrm{~s}$, were performed over the San Joaquin Valley, CA (SJV) (Castle airport, Merced: $37.381^{\circ} \mathrm{N}, 120.568^{\circ} \mathrm{W}$ ), and offshore (RAINS Intersection: $\left.37.169^{\circ} \mathrm{N}, 123.235^{\circ} \mathrm{W}\right)$. Takeoff time from Moffett Field was at 18:00 UTC on 14 May 2012 and 5 June 2012. The aircraft arrived on-station at the SJV site at $\sim 18: 20$ UTC (local time is UTC $-7 \mathrm{~h}$ ) on each day and performed a descending spiral profile from $\sim 8.8 \mathrm{~km}$ to $<0.5 \mathrm{~km}$ with a descent rate of $\sim 370 \mathrm{~m} \mathrm{~min}^{-1}$. A second descending spiral profile was performed over the offshore location each day starting at $\sim$ 19:05 UTC. On the 14 May 2013, the profile extended from $\sim 8.5 \mathrm{~km}$ to $1.5 \mathrm{~km}$; the aircraft was prevented from flying any lower on this day due to a thick marine stratus layer with a top at $1.5 \mathrm{~km}$. The lowest altitude of the offshore profile on 5 June 2012 was $<0.5 \mathrm{~km}$. Total flight time each day was $100 \mathrm{~min}$.

\subsection{RAQMS model description}

Global in-line $\mathrm{O}_{3}$ and meteorological forecasts from RAQMS (Pierce et al., 2007, 2009) are used in conjunction with reverse domain filling (RDF) techniques (Sutton et al., 1994; Fairlie et al., 2007) to provide a large scale context for the interpretation of the airborne observations and to assess the fidelity of the RAQMS $\mathrm{O}_{3}$ forecasts. Forecasts are initialized with satellite-based $\mathrm{O}_{3}$ analyses and are archived at $6 \mathrm{~h}$ intervals at a horizontal resolution of $1^{\circ} \times 1^{\circ}$ with $35 \mathrm{hy}-$ brid $\eta-\theta$ vertical levels extending from the surface to approximately $60 \mathrm{~km}$. Stratospheric $\mathrm{O}_{3}$ analyses are constrained through assimilation of near-real-time (NRT) $\mathrm{O}_{3}$ profiles from the Microwave Limb Sounder (MLS) (Waters et al., 2006) above 50 mbar and NRT cloud-cleared total column $\mathrm{O}_{3}$ retrievals from the Ozone Monitoring Instrument (OMI) (Levelt et al., 2006). The RAQMS dynamical core is the University of Wisconsin (UW) hybrid isentropic-eta coordinate (UW hybrid) model (Zapotocny et al., 1997; Schaack et al., 2004), which uses isentropic coordinates above $380 \mathrm{~K}$ and hybrid eta coordinates between $380 \mathrm{~K}$ and the surface. The vertical resolution depends on the vertical gradient of potential temperature and varies between $\sim 200 \mathrm{~m}$ and $1 \mathrm{~km}$ (Pierce et al., 2007). Meteorological forecasts are initialized with operational analyses from the National Centers for Environmental Prediction (NCEP) Global Data Assimilation System (GDAS) (Kleist et al., 2009). Six-hour chemical and meteorological forecasts provide chemical and meteorological input for the RDF calculations. Analyzed $\mathrm{O}_{3}$ results are plotted as curtains along the flight track for comparison to the in situ data. 


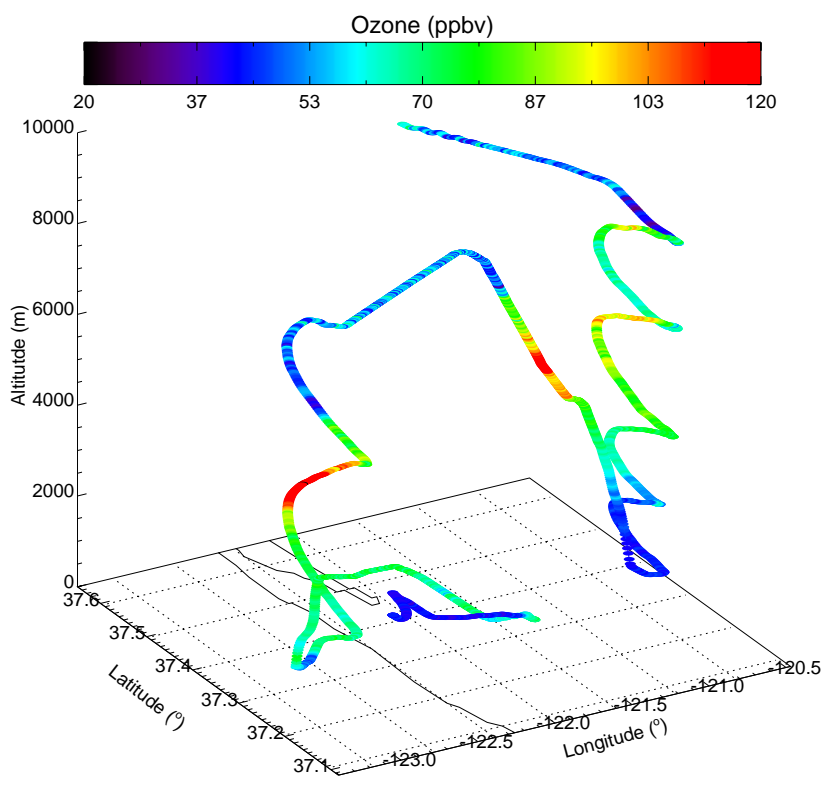

Fig. 1. 3-D projection of $\mathrm{O}_{3}$ mixing ratio (ppbv) as observed during flight on 14 May 2012 (takeoff time: 18:00 UTC). The $\mathrm{O}_{3}$ monitor requires a $10 \mathrm{~min}$ warm-up period before stable measurements are made, which results in data acquisition starting at $8.4 \mathrm{~km}$ during the transit to the San Joaquin Valley (inland) site.

The RDF technique has been shown to represent coarsely resolved constituent fields at higher resolution, with higher information content, than originally observed (Sutton et al., 1994) or modeled (Fairlie et al., 2007). The RAQMS RDF calculations are based on analysis of back trajectories initialized along the aircraft flight track. Three-dimensional 6-day back trajectory calculations were conducted using the Langley Trajectory Model (LTM) (Pierce and Fairlie, 1993; Pierce et al., 1994). Back trajectories are initialized at model hybrid levels every 5 min along the flight track to construct a curtain. The back trajectories sample and archive RAQMS chemical and dynamical quantities so that Lagrangian averages could be determined. The Lagrangian averages, time averages following a given trajectory, are then mapped back onto the initial flight curtain to produce the RDF products. For the STT analysis we focus on $\mathrm{RDF} \mathrm{O}_{3}$, large-scale mixing efficiency, and continental planetary boundary layer (PBL) exposure.

\section{Results and discussion}

\subsection{A cutoff low event: 14 May 2012}

The flight profile and $\mathrm{O}_{3}$ mixing ratios encountered along the 14 May 2012 flight are presented in Fig. 1. Anomalously high $\mathrm{O}_{3}$ mixing ratios $>120 \mathrm{ppbv}$ are found between 4 and $7 \mathrm{~km}$, with a maximum of $150 \mathrm{ppbv}$, creating a steep $\mathrm{O}_{3}$ gradient between the free troposphere and boundary layer.
The high $\mathrm{O}_{3}$ mixing ratios were sampled inside a cutoff low-pressure system. The cutoff low is associated with relatively strong $\mathrm{PV}$ and high $\mathrm{O}_{3}$ extending from the lower stratosphere into the mid-troposphere. $\mathrm{PV}$ is a conservative tracer under adiabatic conditions and is typically much larger in the stratosphere than troposphere; as such, cross sections of PV indicate descent of stratospheric air masses into the troposphere. Figure 2 shows the $5 \mathrm{~km}$ maps and $122^{\circ} \mathrm{W}$ cross sections of enhanced $\mathrm{O}_{3}$ and PV at 18:00 UTC on 14 May 2012.

Figure 3 shows in situ measurements of potential temperature and dew point (Fig. 3a) and $\mathrm{O}_{3}, \mathrm{CO}_{2}$ and water vapor (Fig. 3b, c). Potential temperature and dew point are taken from the most proximal radiosonde launches (Oakland $(\mathrm{OAK}))$ and clearly identify a stable layer at $1.7 \mathrm{~km}$, which existed before (dotted lines) and persisted after (solid lines) the time of the aircraft measurements. A pronounced dry, stable layer is present at $5.8 \mathrm{~km}$ in the radiosonde sounding taken $\sim 5 \mathrm{~h}$ after aircraft measurements, identifying the vertical extent of the intrusion, associated with the cutoff low. This was not evident in the preceding radiosonde sounding as at that time the center of the cutoff low was still located to the west of OAK.

The $\mathrm{O}_{3}, \mathrm{CO}_{2}$ and water vapor mixing ratios observed during each profile are shown in Fig. 3b (offshore) and Fig. 3c (SJV). $\mathrm{CO}_{2}$ is a non-conventional tracer of stratospheric air and provides an interesting comparison between stratospheric and tropospheric air masses. A clear increase in $\mathrm{O}_{3}$ is observed between 4 and $7 \mathrm{~km}$, a decrease in $\mathrm{CO}_{2}$ between 4.5 and $5.5 \mathrm{~km}$ and reduced water vapor mixing ratios $(<0.015$ percent by volume $(\% \mathrm{v}))$ at altitudes greater than $4 \mathrm{~km}$ in the offshore profile. Similar features are seen in the SJV profile, with an increase in $\mathrm{O}_{3}$ from $>2 \mathrm{~km}$ to $5.5 \mathrm{~km}$ and at $7 \mathrm{~km}$, and a reduction in $\mathrm{CO}_{2}$ and $\mathrm{H}_{2} \mathrm{O}$ mixing ratios at altitudes greater than $2 \mathrm{~km}$, indicating the top of the boundary layer. The perturbations are more pronounced in the offshore profile, compared to the SJV profile where the $\mathrm{O}_{3}$ lamina is more vertically spread and as such has a slightly lower overall maximum $\mathrm{O}_{3}$ mixing ratio. However, the $\mathrm{O}_{3}$ maximum and $\mathrm{CO}_{2}$ and water vapor minima in both profiles are located near $5 \mathrm{~km}$.

$\mathrm{CO}_{2}$ can be viewed as a more inert tracer than $\mathrm{O}_{3}$, since it has no known sinks in the lower stratosphere (Aoki et al., 2003). The seasonal cycle of tropospheric $\mathrm{CO}_{2}$ has a large amplitude characterized by a maximum in spring (April/May in the Northern Hemisphere) and minimum in summer (July) (Nakazawa et al., 1991; Boering et al., 1996; Hoor et al., 2004; Gurk et al., 2008; Sawa et al., 2008). In the lower stratosphere $\mathrm{CO}_{2}$ has a less pronounced seasonal cycle with low concentrations in winter-spring and higher concentrations in summer. From the seasonal cycle information presented by Gurk et al. (2008) and Sawa et al. (2008), we expect stratospheric $\mathrm{CO}_{2}$ mixing ratios during the time of this study (May-early June) to be less than tropospheric $\mathrm{CO}_{2}$ mixing ratios, as observed within the intrusion, on 14 May 

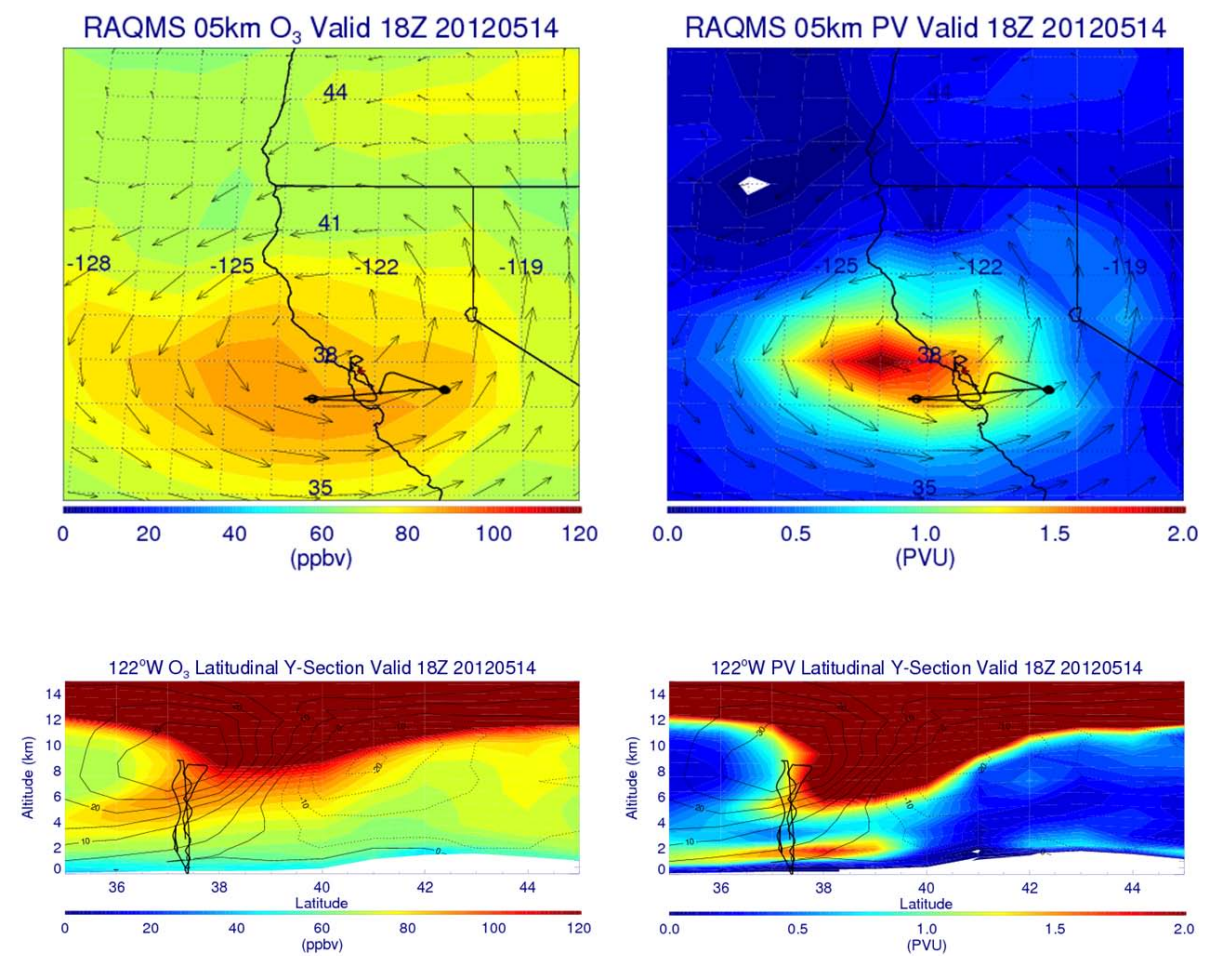

Fig. 2. $5 \mathrm{~km} \mathrm{O}_{3}$ (ppbv) and wind vector (black, upper left) and $\mathrm{PV}$ (PVU) and wind vector (black, upper right) maps with $\mathrm{O}_{3}$ (ppbv, lower left) and PV (PVU, lower right) cross sections at $122^{\circ} \mathrm{W}$ on 14 May 2012 at 18:00 UTC from the RAQMS analyses. The aircraft flight track is shown in black. Oakland, located on the San Francisco East Bay, is shown as a red star. Note the cutoff low associated with relatively strong PV (bottom right) and high $\mathrm{O}_{3}$ (bottom left) extending from the lower stratosphere into the mid-troposphere. The flight track and observations were taken in a region were PV is <2 PVU (bottom right), indicating STT occurrence (i.e., stratospheric air was sampled after crossing the tropopause). Black contours represent wind speed in $\mathrm{m} \mathrm{s}^{-1}$.
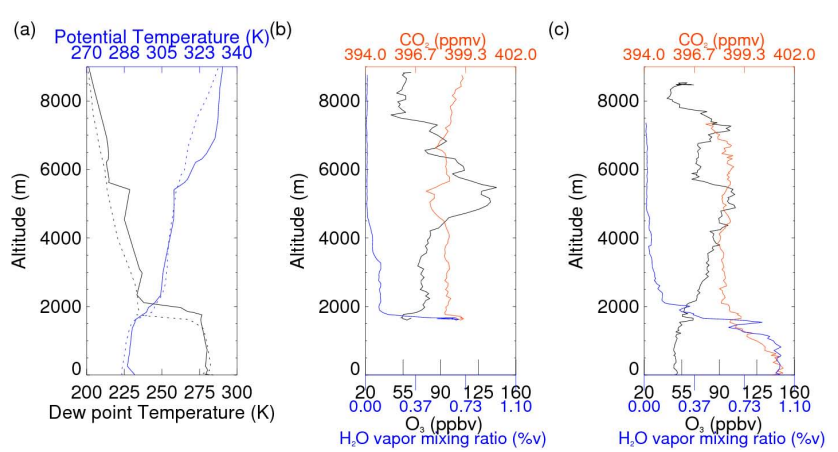

Fig. 3. (a) Potential temperature (blue) and dew point (black) soundings at Oakland, CA, on 14 May 2012 at 12:00 UTC (dotted lines) and 15 May 2012 at 00:00 UTC (solid lines). Oakland is $\sim 140 \mathrm{~km}$ from the San Joaquin Valley (inland) site and $\sim 100 \mathrm{~km}$ from the offshore site. Mixing ratios of $\mathrm{O}_{3}$ (black), $\mathrm{CO}_{2}$ (red) and $\mathrm{H}_{2} \mathrm{O}$ (blue) observed (b) offshore, and (c) over the San Joaquin Valley during vertical profiles on 14 May 2012.

2012. As such, at this time of year in the Northern Hemisphere, $\mathrm{CO}_{2}$ measurements collocated with $\mathrm{O}_{3}$ and water vapor can be used as tracers of STT. The use of additional tracers, such as $\mathrm{CO}_{2}$, further confirms the observed $\mathrm{O}_{3}$ lamina to be stratospheric in nature as opposed to aged and lofted Asian pollution, where $\mathrm{CO}_{2}$ mixing ratios would be expected to be representative of tropospheric values.

Figure 4 shows results of the RAQMS RDF curtain calculations for this flight along with the analyzed $\mathrm{O}_{3}$ curtain (as described in Sect. 2.1). The RAQMS RDF O $\mathrm{O}_{3}$ shows a much sharper vertical gradient in the upper troposphere than the analyzed $\mathrm{O}_{3}$ with $\mathrm{RDF} \mathrm{O}_{3}$ in excess of $120 \mathrm{ppbv}$ below and $60 \mathrm{ppbv}$ above $8 \mathrm{~km}$. The sharp vertical gradients in the RDF calculation arise due to vertical shear, which leads to different horizontal sampling along the back trajectories and very different Lagrangian mean air-mass histories at different altitudes. To determine which parts of the flight curtain may have been exposed to air within the continental PBL, we track the amount of time each back trajectory spent within the continental PBL or is linked to the continental PBL via convective mixing and then use 7-day (7-14 May 2013) averaged total column carbon monoxide (CO) from the Atmospheric Infrared Sounder (AIRS) (Aumann and Miller, 1995) to distinguish between exposure to clean and polluted continental PBL air. An AIRS total column CO threshold of $2.5 \times 10^{8}$ molecules $\mathrm{cm}^{-2}$ was used distinguish between clean and polluted continental boundary layer 

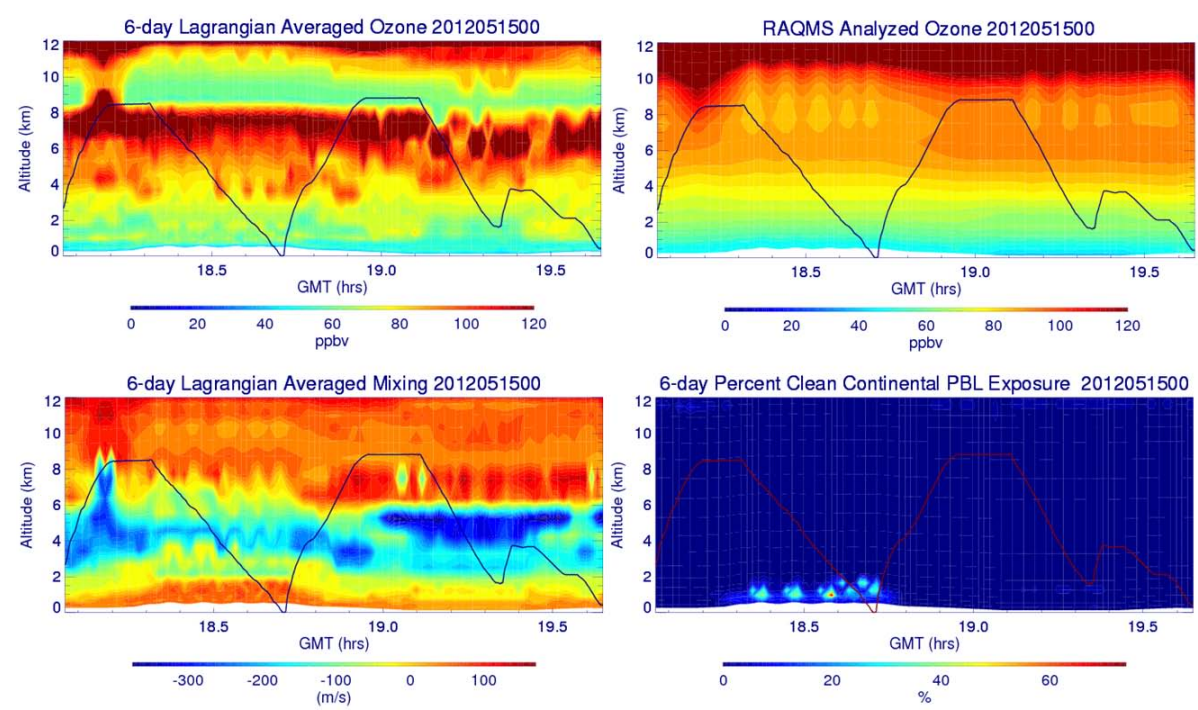

Fig. 4. RAQMS RDF $\mathrm{O}_{3}$ (ppbv, upper left), analyzed $\mathrm{O}_{3}$ (ppbv, upper right), RDF mixing efficiency ( $\mathrm{m} \mathrm{s}^{-1}$, lower left), and $\%$ clean continental PBL exposure (\%, lower right) for AJAX flight on 14 May 2012.

exposure. By monitoring the amount of time that the back trajectories spent within either clean or polluted continental PBL, we can see that the air in the vicinity of the cutoff low was not within a clean continental PBL during the previous 6 days. The RAQMS RDF calculations predict no exposure to polluted continental PBL air along the aircraft flight track (not shown), which is consistent with the observed $\mathrm{CO}_{2}$.

The RDF mixing curtain provides a measure of the efficiency of large-scale mixing along the back trajectories and is determined from the Lagrangian averaged rate of stretching of air parcels (Haynes and McIntyre, 1990; Fairlie et al., 2007). Regions of large positive RDF mixing (warm colors) are associated with strong shear flow where neighboring air parcels can mix efficiently. Regions of large negative RDF mixing (cool colors) are associated with rotational flow, where air parcels tend to remain more isolated. After 18:40 UTC (18.7 UTC), and above $6 \mathrm{~km}$, the 14 May 2012 STT is associated with efficient large-scale mixing along the southern flank of the cutoff low, which leads to stretching of the air parcels and generation of laminar ozone features. Prior to $18: 40$ UTC (18.7 UTC) and below $6 \mathrm{~km}$, the RDF curtain is within the rotational flow associated with the cutoff low (see Fig. 2); RDF mixing is negative, indicating that the air parcels have remained relatively isolated, inhibiting mixing between free-tropospheric and stratospheric air parcels.

This cutoff low provides an opportunity to evaluate the ability of the RAQMS $\mathrm{O}_{3}$ analysis and RAQMS RDF $\mathrm{O}_{3}$ to capture the observed structure of the $\mathrm{O}_{3}$ lamina and to assess the influence of numerical diffusion on predicted transport of stratospheric air into the troposphere. Figure 5 shows comparisons between the in situ $\mathrm{O}_{3}$ measurements, RAQMS $\mathrm{O}_{3}$ analyses, and RAQMS RDF $\mathrm{O}_{3}$ along the aircraft flight track. The first encounter with the $\mathrm{O}_{3}$ lamina occurs prior to $18: 30$ UTC (18.5 UTC) during the descending portion of the onshore (SJV) profile. During this flight leg both the RAQMS-analyzed and $\mathrm{RDF} \mathrm{O}_{3}$ overestimate the observed $\mathrm{O}_{3}$ mixing ratio, but the $\mathrm{RDF} \mathrm{O}_{3}$ captures the sharp vertical variations much better than the analyzed $\mathrm{O}_{3}$. Between 18:30 UTC and 18:48 UTC (18.5-18.8 UTC) the aircraft descends below $6 \mathrm{~km}$ and then begins to ascend again. During this time period, when the aircraft is sampling within the cutoff low and the air is isolated from large-scale mixing, both the RAQMS RDF and analyzed $\mathrm{O}_{3}$ are in relatively good agreement with the in situ $\mathrm{O}_{3}$. Between 18:48 UTC and 19:12 UTC (18.8-19.2 UTC) the aircraft completes the ascending portion of the onshore profile, reaches maximum altitude, and conducts the descending portion of the offshore profile. During these legs the aircraft penetrates through the $\mathrm{O}_{3}$ lamina twice, with in situ $\mathrm{O}_{3}$ ranging from $120 \mathrm{ppbv}$ to 140 ppbv within the $\mathrm{O}_{3}$ lamina and $60 \mathrm{ppbv}$ above. The RDF $\mathrm{O}_{3}$ does a very good job in capturing this variation while the analyzed $\mathrm{O}_{3}$ shows a much broader $\mathrm{O}_{3}$ peak. The narrow $\mathrm{O}_{3}$ lamina captured by the $\mathrm{RDF} \mathrm{O}_{3}$ analysis is poorly resolved because of the relatively coarse horizontal and vertical resolution of RAQMS. As the scale of the $\mathrm{O}_{3}$ lamina approaches the RAQMS grid dimensions, numerical diffusion becomes very large and the narrow feature is lost. After 19:12 UTC (19.2 UTC) the aircraft is again below $6 \mathrm{~km}$ and within the cutoff low where rotational flow dominates, and both the $\mathrm{RDF}$ and analyzed $\mathrm{O}_{3}$ are in good agreement with the in situ measurements.

The RAQMS back trajectories can be used to examine the history of the high (> $120 \mathrm{ppbv}$ ) $\mathrm{RDF} \mathrm{O}_{3}$ predicted within the $\mathrm{O}_{3}$ lamina. Figure 6 shows the back trajectory history and locations of the Lagrangian averaged, high (>120 ppbv) RDF $\mathrm{O}_{3}$ mixing ratios beginning at 18:00 UTC on 8 May 2012, 


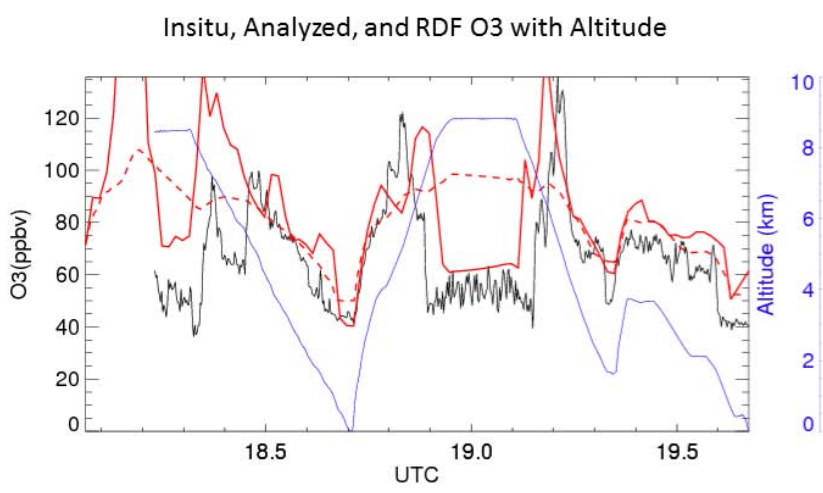

Fig. 5. Time series of in situ (black), RAQMS reverse domain filled (RDF) (solid red), and RAQMS-analyzed (dashed red) $\mathrm{O}_{3}$ (ppbv) for AJAX flight on 14 May 2012. The in situ $\mathrm{O}_{3}$ data acquisition starts during the transit to the San Joaquin Valley (SJV) site. The first vertical profile is over the SJV and second vertical profile over the offshore location. The RDF approach provides much better agreement with the in situ observations.

6 days prior to being sampled by the aircraft. The underlying map on the top of Fig. 6 shows 7-day averaged total column $\mathrm{O}_{3}$ from AIRS during the period from 7 to 14 May 2012 . The back trajectories show a significant amount of dispersion over the previous 6 days, with meridional spread in the back trajectories within the first 2-3 days and longitudinal spread 3-6 days prior to sampling by the aircraft. The majority of the high $\mathrm{RDF} \mathrm{O}_{3}$ values along the aircraft curtain were located to the south of a region of high mean column $\mathrm{O}_{3}$ off the coast of Asia 6 days prior to sampling. At this time, the location of the air within the $\mathrm{O}_{3}$ lamina that was sampled by the aircraft is an elongated region extending north eastward from South Korea over southern Japan to about $45^{\circ} \mathrm{N}$ at the International Date Line. The bottom of Fig. 6 shows the RAQMS-analyzed $\mathrm{O}_{3}$ and zonal wind $135^{\circ} \mathrm{E}$ cross section at 18:00 UTC on 8 May 2012. The cross section shows that the air within the sampled $\mathrm{O}_{3}$ lamina was located between 10 and $12 \mathrm{~km}$ on the northern flank of a strong $\left(>60 \mathrm{~m} \mathrm{~s}^{-1}\right)$ westerly jet at this time. There are strong meridional gradients in $\mathrm{O}_{3}$ across the jet axis, with high stratospheric $\mathrm{O}_{3}$ on the poleward and lower $\mathrm{O}_{3}$ on the equatorward side of the jet. Analysis of the back trajectories from the observed $\mathrm{O}_{3}$ lamina at 18:00 UTC on 8 May 2012 shows that mean $\mathrm{O}_{3}$ mixing ratio at the location at 18:00 UTC on 8 May 2012 is $163 \mathrm{ppbv}$ with a standard deviation of $50 \mathrm{ppbv}$. Efficient large-scale mixing of this initial distribution with lower mixing ratio $\mathrm{O}_{3}$ within the troposphere as well as numerical diffusion results in reductions in the mean and standard deviation in the analyzed $\mathrm{O}_{3}$ lamina to $97 \mathrm{ppbv}$ and $7.5 \mathrm{ppbv}$, respectively, when it is sampled by the aircraft on 14 May 2012.

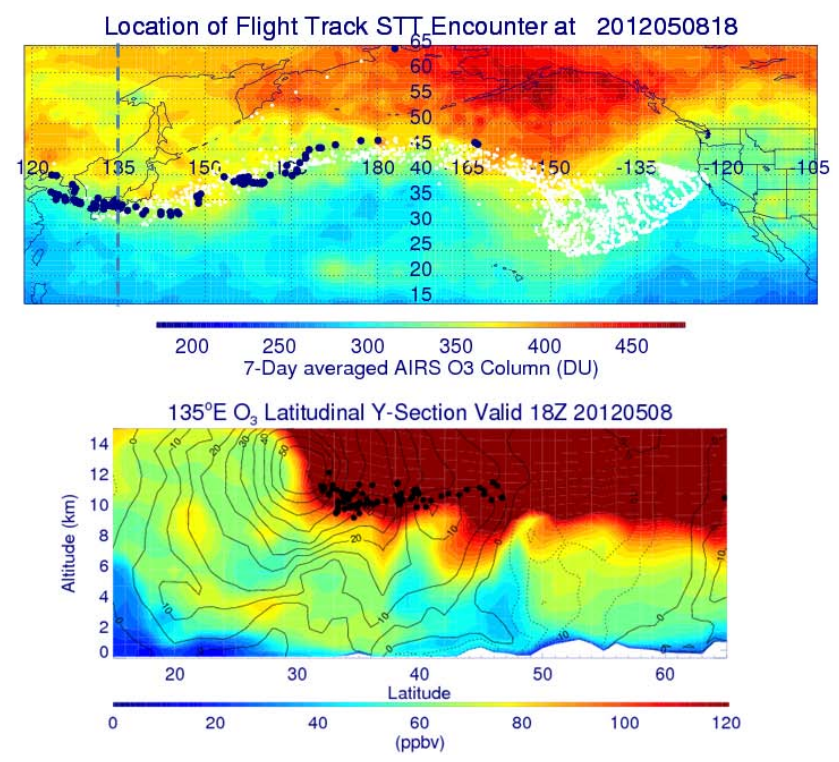

Fig. 6. Map of 7-day averaged (7-14 May 2012) AIRS total column $\mathrm{O}_{3}$ (DU, top) with the STT back trajectory history (white) and locations of the high (>120 ppbv) $\mathrm{RDF} \mathrm{O}_{3}$ mixing ratios (blue). RAQMS $135^{\circ} \mathrm{E} \mathrm{O}_{3}$ (ppbv) and zonal wind (black contours, $\mathrm{m} \mathrm{s}^{-1}$ ) cross section (bottom) with locations of the high (>120 ppbv) RDF $\mathrm{O}_{3}$ mixing ratios (blue dots) at 18:00 UTC on 8 May 2012 for analysis of AJAX flight on 14 May 2012.

\subsection{A post-trough, building ridge event: 5 June 2012}

A deep, late-season extratropical cyclone affected California on 5 June 2012 and injected stratospheric air into the troposphere, by means of a tropopause fold. The tropopause fold observed on 5 June 2012 was more pronounced, when comparing maximum $\mathrm{O}_{3}$ mixing ratios in each $\mathrm{O}_{3}$ lamina, than the event on 14 May 2012. Anomalously high $\mathrm{O}_{3}$ mixing ratios were observed between 3 and $4 \mathrm{~km}$, creating a steep $\mathrm{O}_{3}$ gradient between $\mathrm{O}_{3}$ within the tropopause fold (up to $120 \mathrm{ppbv}$ offshore and $200 \mathrm{ppbv}$ over SJV) and $\mathrm{O}_{3}$ in surrounding air masses (40 and $50 \mathrm{ppbv}$ offshore and over SJV respectively).

Figure 7 shows $4 \mathrm{~km}$ maps and $120^{\circ} \mathrm{W}$ cross sections of RAQMS $\mathrm{O}_{3}$ and PV at 18:00 UTC on 5 June 2012. An extensive region of enhanced $\mathrm{O}_{3}$ and $\mathrm{PV}$ over central California at $4 \mathrm{~km}$ is being advected in from the northwest behind the trough. The RAQMS-analyzed $\mathrm{O}_{3}$ is greater than $80 \mathrm{ppbv}$, and $\mathrm{PV}$ is in excess of 1.5 PVU indicating that stratospheric air $(\mathrm{PV}>2 \mathrm{PVU})$ has crossed the tropopause. This enhanced $\mathrm{O}_{3}$ and $\mathrm{PV}$ extends down into the troposphere along the northern flank of a relatively strong $\left(45 \mathrm{~m} \mathrm{~s}^{-1}\right)$ jet at $120^{\circ} \mathrm{W}$. The aircraft flight path intersects the high $\mathrm{O}_{3}$ and PV during the SJV profile and appears to be just to the south of the enhancement at $4 \mathrm{~km}$ during the offshore profile.

Radiosonde launches from OAK observed the tropopause fold as a dry stable region (Fig. 8a) near $3.5 \mathrm{~km}$ in the 5 June 

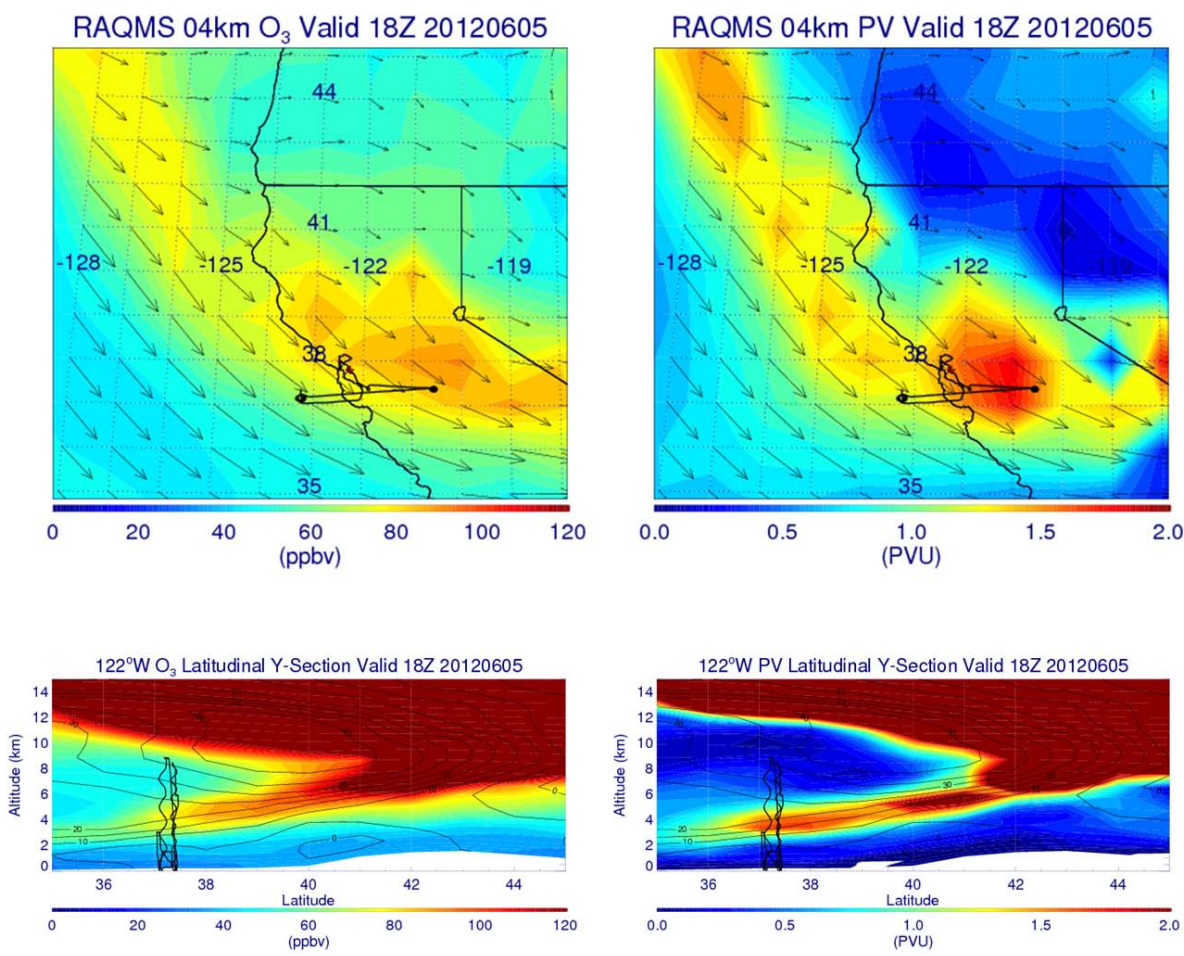

Fig. 7. $4 \mathrm{~km} \mathrm{O}_{3}$ (ppbv) and wind vectors (black, upper left) and $\mathrm{PV}$ (PVU) and wind vectors (black, upper right) maps with $\mathrm{O}_{3}$ (ppbv, lower left) and PV (PVU, lower right) cross sections at 120 $\mathrm{W}$ on 5 June 2012 at 18:00 UTC from the RAQMS analyses. The aircraft flight track is shown in black, Oakland, located on the San Francisco East Bay, is shown as a red star. Note the tropopause fold indicated by the tongue of relatively strong PV and high $\mathrm{O}_{3}$ extending from the lower stratosphere into the mid-troposphere. The flight track and observations were taken in a region were PV is < 2 PVU (bottom right), indicating STT occurrence (i.e., stratospheric air was sampled after crossing the tropopause).

2012, 12:00 UTC, radiosonde sounding (dotted lines) and at $3 \mathrm{~km}$ in the 6 June 2012, 00:00 UTC, radiosonde sounding (solid lines). $\mathrm{O}_{3}, \mathrm{CO}_{2}$ and water vapor mixing ratios observed during each profile are shown in Fig. $8 \mathrm{~b}$ (offshore) and Fig. 8c (SJV). $\mathrm{O}_{3}$ increases between $2.8-4 \mathrm{~km}$ offshore and $3.5-4.3 \mathrm{~km}$ over the $\mathrm{SJV}$; an $\mathrm{O}_{3}$ maximum in both instances is observed at $3.7 \mathrm{~km}$. The $\mathrm{O}_{3}$ increase is more pronounced in the SJV profile, compared to the offshore location. Also, in both profiles there are decreases in $\mathrm{CO}_{2}$ and water vapor mixing ratios at the same altitudes as the $\mathrm{O}_{3}$ increases, corroborating the assignment of stratospheric origin.

Figure 9 shows results of the RAQMS RDF curtain calculations for this flight along with the analyzed $\mathrm{O}_{3}$ curtain. The RDF and analyzed $\mathrm{O}_{3}$ both show $\mathrm{O}_{3}$ enhancements near $4 \mathrm{~km}$ during the first half of the flight (SJV profile), although the $\mathrm{RDF} \mathrm{O}_{3}$ shows sharper gradients and higher (>100 ppbv) mixing ratios than the analyzed $\mathrm{O}_{3}$. Neither RDF nor analyzed $\mathrm{O}_{3}$ shows significant enhancements during the latter half of the flight (offshore profile) with peak $\mathrm{O}_{3}$ mixing ratios generally less than 70 ppbv at $3-4 \mathrm{~km}$. The RDF mixing curtain shows that the lower half of the tropopause fold is associated with negative mixing efficiencies, indicating that this air has remained relatively isolated during the previous 6 days.
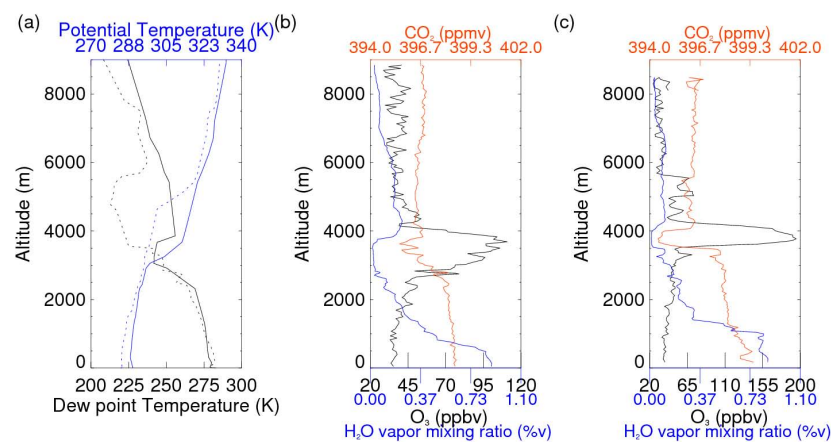

Fig. 8. (a) Potential temperature (blue) and dew point (black) soundings at Oakland, CA, on 5 June 2012 at 12:00 UTC (dotted lines) and 6 June 2012 at 00:00 UTC (solid lines). Mixing ratios of $\mathrm{O}_{3}$ (black), $\mathrm{CO}_{2}$ (red) and $\mathrm{H}_{2} \mathrm{O}$ (blue) observed (b) offshore, and (c) over the San Joaquin Valley during descending, vertical profiles on 5 June 2012. Note the change of the $\mathrm{O}_{3}$ horizontal scale between panels.

The RDF clean continental PBL exposure curtain shows that the tropopause fold has not been exposed to the clean continental PBL air during the previous 6 days prior to being sampled by the aircraft. The RAQMS RDF calculations predict 
no exposure to polluted continental boundary layer air along the aircraft flight track (not shown).

Figure 10 shows comparisons between the in situ $\mathrm{O}_{3}$ measurements, RAQMS $\mathrm{O}_{3}$ analyses, and RAQMS RDF $\mathrm{O}_{3}$ along the aircraft flight track. The aircraft samples the tropopause fold three times prior to 19:00 UTC. During this period the $\mathrm{RDF} \mathrm{O}_{3}$ shows narrower features and somewhat higher mixing ratios than the analyzed $\mathrm{O}_{3}$, but neither is able to capture the amplitude of the observed $\mathrm{O}_{3}$ peak, which is greater than $150 \mathrm{ppbv}$ during each of the three encounters and reaches $190 \mathrm{ppbv}$ at 18:42 UTC (18.7 UTC) during the SJV profile. The aircraft is above the tropopause fold, between the first and second tropopause fold encounters, and the RDF $\mathrm{O}_{3}$ captures the sharp vertical gradients and shows generally better agreement with the in situ measurements. The aircraft is below the tropopause fold between the second and third tropopause fold encounters, and both RDF and analyzed $\mathrm{O}_{3}$ are in good agreement with the in situ measurements. The aircraft encounters the tropopause fold once at 19:30 UTC (19.5 UTC) during the offshore profile with both RDF and analyzed $\mathrm{O}_{3}$ showing significant underestimates in $\mathrm{O}_{3}$. Between 19:36 and 19:48 UTC (19.6-19.8 UTC), the aircraft samples marine boundary layer where both the RDF and analyzed $\mathrm{O}_{3}$ are in good agreement with the in situ measurements. The tropopause fold is sampled for the fifth time between 19:54 and 20:00 UTC (19.9-20.0 UTC), and both RDF and analyzed $\mathrm{O}_{3}$ capture the observed vertical gradient, but miss the high $\mathrm{O}_{3}$ within the tropopause fold by up to $50 \mathrm{ppbv}$.

The RAQMS back trajectories are used to examine the history of the relatively high (> $80 \mathrm{ppbv}) \mathrm{RDF} \mathrm{O}_{3}$ predicted within the onshore tropopause fold feature. Figure 11 shows the back trajectory history and location of the high (> 80 ppbv) $\mathrm{RDF} \mathrm{O}_{3}$ mixing ratios beginning at 18:00 UTC on 30 May 2012, 6 days prior to being sampled by the aircraft. The underlying map on the top of Fig. 11 shows 7day averaged total column $\mathrm{O}_{3}$ from AIRS during the period from 29 May to 5 June 2012. During the first day prior to being sampled by the aircraft, the tropopause fold back trajectories remain very compact and move northwestward into a region south of Alaska with high AIRS average total column $\mathrm{O}_{3}$. Three days prior to being sampled by the aircraft, some of the tropopause fold back trajectories are dispersed further westward into the region of high AIRS average total column $\mathrm{O}_{3}$ over Japan and Siberia. However, the majority of the tropopause fold back trajectories remain south of Alaska and circulate within a large, stationary low-pressure system near $150^{\circ} \mathrm{W}$. The bottom plot of Fig. 11 shows the RAQMS-analyzed $\mathrm{O}_{3}$ and zonal wind $150^{\circ} \mathrm{W}$ cross section at 18:00 UTC on 30 May 2012. The tropopause fold back trajectories were located within the core of the stationary lowpressure system in a region of moderately high $\mathrm{O}_{3}$ and low wind speeds between 6 and $8 \mathrm{~km}$ at this time. Analysis of the tropopause fold back trajectories at 18:00 UTC on 30 May 2012 shows that mean $\mathrm{O}_{3}$ mixing ratios at their location is $102 \mathrm{ppbv}$ with a standard deviation of $14 \mathrm{ppbv}$, both of which are significantly lower than found within the histories of the 14 May 2012 tropopause fold encounter. The low initial variance of the 5 June 2012 tropopause fold back trajectories, combined with the fact that this tropopause fold encounter was associated with relatively isolated air and weak largescale mixing, accounts for the smaller differences between the RDF and analyzed $\mathrm{O}_{3}$ for this flight and indicates that processes other than large-scale shear lead to the fine filament structure observed on this flight. It is possible that differential transport by inertia gravity waves could have contributed to the formation of the thin filament of high $\mathrm{O}_{3}$, given the close proximity of the flight to a strong jet core (see Fig. 7). For example, previous studies have reported signatures of small-scale vertical structures induced by inertia gravity waves in temperature, wind and ozone profiles (e.g., Danielsen et al., 1991; Pierce and Fairlie, 1993; Chane-Ming et al., 2003; Plougonven et al., 2003).

\subsection{Stratosphere-to-troposphere implications}

Due to changes in terrain and vertical transport, it is difficult to compare $\mathrm{O}_{3}$ directly from two or more vertical profiles at a particular altitude alone. Thus, to assess the contribution of the two STT events on the total mass of $\mathrm{O}_{3}$ within the observed vertical profiles, the total measured $\mathrm{O}_{3}$ was calculated in Dobson units (DU) based upon the summation of the measured $\mathrm{O}_{3}$ within a particular layer of the atmosphere (here, measurements below $\sim 9 \mathrm{~km}$ (365 mbar) are used). To account for terrain differences, the total $\mathrm{O}_{3}$ in DU was normalized by dividing by the thickness (mbar) of the atmosphere over which $\mathrm{O}_{3}$ measurements were taken (DU/100 mbar), following the method of Cooper et al. (2011). The STT event on 14 May 2012 had a greater total $\mathrm{O}_{3}$ DU/100 mbar value compared to the 5 June 2012 event, even though the 14 May 2012 STT event had a reduced maximum $\mathrm{O}_{3}$ mixing ratio compared to 5 June 2012. This is because the stratospheric intrusion on 14 May 2012 was more vertically extensive, and $\mathrm{O}_{3}$ enhancements were measured over a wider altitude range compared to the fine filament structure observed during the 5 June 2012 STT, which resulted in a larger overall enhancement of total $\mathrm{O}_{3}$ within the $0-9 \mathrm{~km}$ layer.

For 14 May 2012, total $\mathrm{O}_{3}$ within the $0-9 \mathrm{~km}$ layer in DU/100 mbar was $6.5 \mathrm{DU} / 100 \mathrm{mbar}$ in the offshore profile and $6.9 \mathrm{DU} / 100 \mathrm{mbar}$ above the SJV, compared to 4.2 and 3.8 DU/100 mbar in the offshore and SJV profiles respectively on 5 June 2012. For comparison, these values are within the range observed during the IONS-2010 campaign in May-June 2010 reported by Cooper et al. (2011), where typical values were within the range of 2-7 DU/100 mbar.

Given the importance of upper tropospheric $\mathrm{O}_{3}$ in terms of its radiative qualities and the fact that some STT events, particularly fine filament structures such as that observed on 5 June 2012, may be difficult to detect by means other than in situ methods, this work highlights the importance of routine collection of tropospheric $\mathrm{O}_{3}$ measurements, with high 

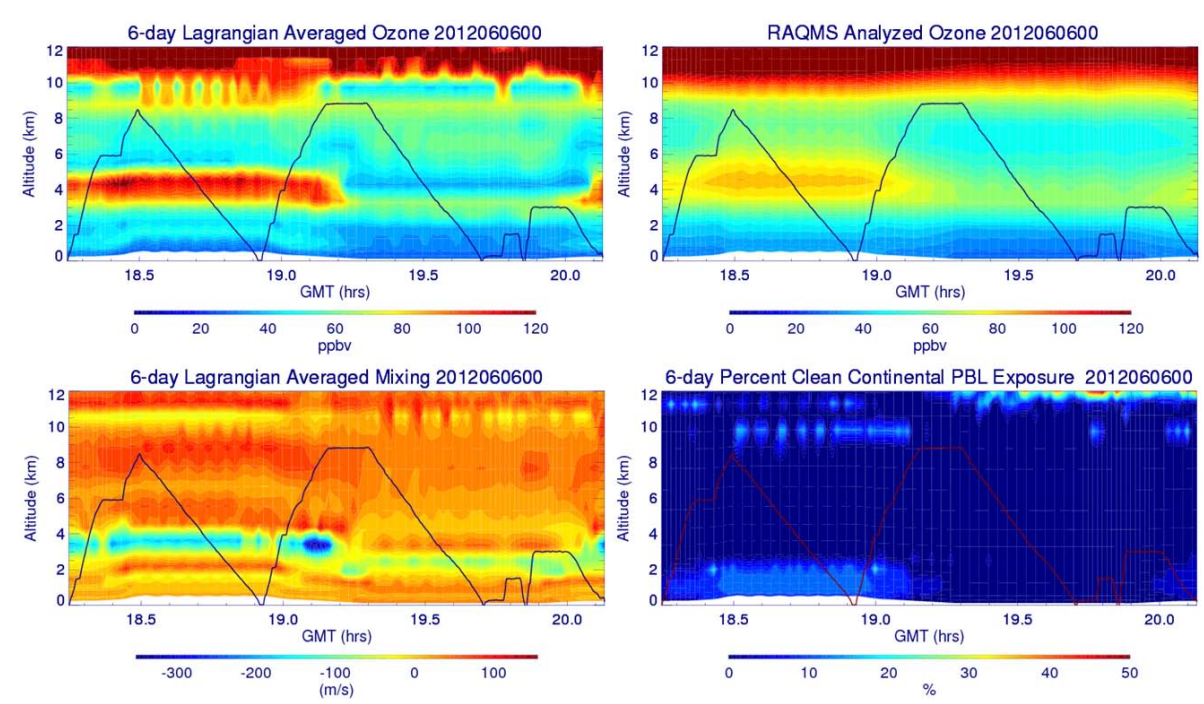

Fig. 9. RAQMS RDF O $\mathrm{O}_{3}$ (ppbv, upper left), analyzed $\mathrm{O}_{3}$ (ppbv, upper right), RDF mixing efficiency ( $\mathrm{m} \mathrm{s}^{-1}$, lower left), and $\%$ clean continental PBL exposure (\%, lower right) for AJAX flight on 5 June 2012.

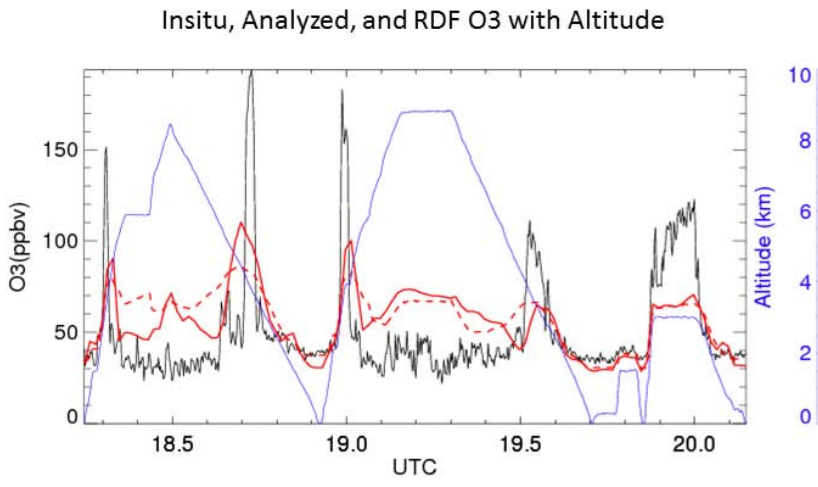

Fig. 10. Time series of in situ (black), RAQMS reverse domain filled (RDF) (solid red), and RAQMS-analyzed (dashed red) $\mathrm{O}_{3}$ (ppbv) for AJAX flight on 5 June 2012. The first vertical profile is over the San Joaquin Valley and second vertical profile over the offshore location.

vertical resolution, to understand the frequency, magnitude and controlling processes of STT better.

The US EPA can currently exclude from the NAAQS $\mathrm{O}_{3}$ target any surface $\mathrm{O}_{3}$ monitoring data identified as being influenced by an extreme stratospheric intrusion, since the naturally occurring "exceptional events" are uncontrollable by state agencies. However, identification of STT contributing to surface $\mathrm{O}_{3}$ sites remains challenging for several reasons, including a lack of vertical $\mathrm{O}_{3}$ measurements, which identify the extent of the intrusion, and the limited effectiveness of models in forecasting the impacts of STT in part due to the complex topography of the western United States and resulting mesoscale dynamics (e.g., mountain lee waves and low-level jets). Furthermore, stratospheric intrusions can remain aloft or contribute to the overall background by grad-

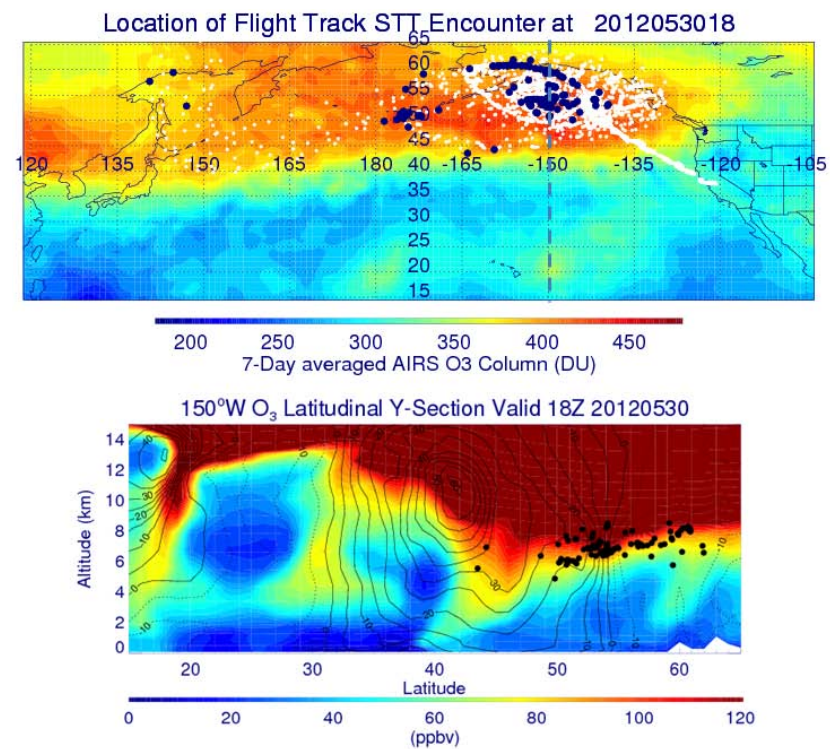

Fig. 11. Map of 7-day averaged (30 May-5 June 2012) AIRS total column $\mathrm{O}_{3}$ (DU, top) with the STT back trajectory history (white) and origin (blue) and RAQMS $150^{\circ} \mathrm{W} \mathrm{O}_{3}$ (ppbv) and zonal wind $\left(\mathrm{m} \mathrm{s}^{-1}\right)$ cross section (bottom) with origin of STT encounter (blue dots) at 18:00 UTC on 30 May 2012 for analysis of AJAX flight on 5 June 2012.

ual mixing with the boundary layer making a distinct $\mathrm{O}_{3}$ enhancement difficult to distinguish, and the effects of a stratospheric intrusion may result in an increase of $\mathrm{O}_{3}$ at a surface site during daytime when photochemical processing further complicates identification. The two STT events analyzed here intrude down to $4 \mathrm{~km}$ on 15 May 2012 and $2.8 \mathrm{~km}$ on 5 June 2012 , both of which are deep enough to 


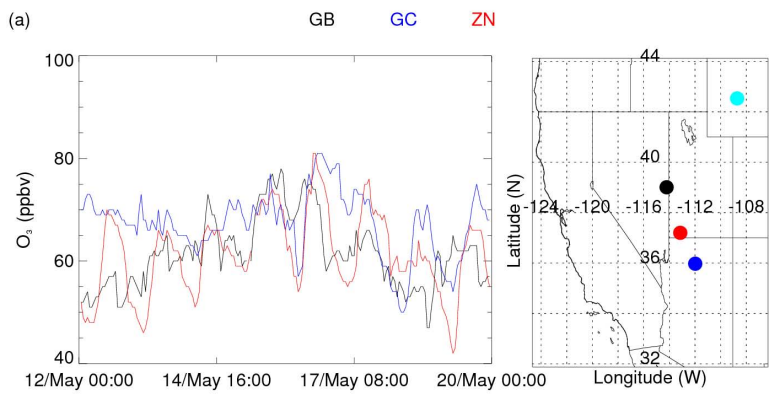

(b)

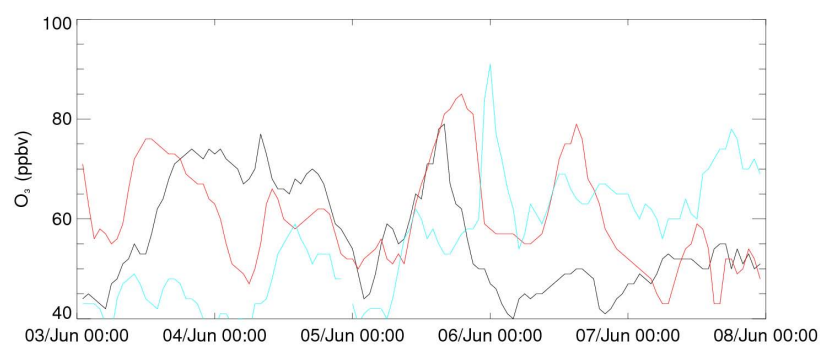

Fig. 12. $\mathrm{O}_{3}$ time series from surface monitoring sites: Great Basin National Park, Nevada (GB, black); Grand Canyon National Park, Arizona (GC, blue); Zion National Park, Utah (ZN, red); and South Pass, Wyoming (WY, cyan), during 12-19 May 2012 (a) and 3-7 June 2012 (b).

be potentially entrained into the boundary layer and impact surface sites, particularly when considering the mountainous terrain of the western United States and convection during springtime, both of which intensify vertical mixing.

Maps of the US EPA air quality index from 5 to 6 June 2012 showed moderate to high $\mathrm{O}_{3}$ over parts of California, Nevada, Utah and Wyoming, with exceedances of the NAAQS $\mathrm{O}_{3}$ standard in southwestern Utah, eastern Nevada and Wyoming (www.airnow.gov). Potential vorticity and $\mathrm{O}_{3}$ from the 18:00 UTC RAQMS analysis for 5 June 2012 also show how the tropopause fold descends to low altitudes $(<4 \mathrm{~km})$ over California, Nevada, Utah and east to $111^{\circ} \mathrm{W}$. To investigate the possibility of STT contributing to surfacelevel $\mathrm{O}_{3}$ further, one-hour $\mathrm{O}_{3}$ mixing ratios were obtained from rural sites in Grand Canyon National Park, Arizona (GC); Great Basin National Park, Nevada (GB); South Pass, Wyoming (WY); and Zion National Park, Utah (ZN).

Assessment of the impacts of STT on surface sites for the 14 May 2012 STT event proved difficult. Air quality maps from 14 May 2012 show enhanced $\mathrm{O}_{3}$ over southern California, southern and eastern Nevada, Arizona and Utah. Timeseries plots of the one-hour surface $\mathrm{O}_{3}$ from GB, ZN and GC show a general increase in the diurnal cycle of surface $\mathrm{O}_{3}$ during 15-16 May 2012 compared to the days before and after. However, there is no distinct enhancement outside of the daytime periods, making the potential contribution from STT difficult to assess (see Fig. 12a).
Enhancements of surface $\mathrm{O}_{3}$ are observed during 5-6 June 2012 (see Fig. 12b). Maximum surface $\mathrm{O}_{3}$ enhancements at GB and $\mathrm{ZN}$ occur on 5 June 2012 reaching $79 \mathrm{ppbv}$ at 16:00 (local time) at GB and $85 \mathrm{ppbv}$ at 19:00 (local time) at $\mathrm{ZN}$. However, the occurrences during daytime hours complicate identification of STT influence at these sites. At the WY site, a distinct increase in $\mathrm{O}_{3}$ is observed with a maximum of $91 \mathrm{ppbv}$ measured at 00:00 (local time) on 6 June 2012. This is clearly not a result of photochemical processing and as such is most likely evidence of the impact of STT at surface sites. An assessment of the meteorological data supports this conclusion; the upper level disturbance, which resulted in the tropopause fold observed in-flight on 5 June 2012, had moved east and was lying directly upstream of the South Pass surface $\mathrm{O}_{3}$ site in western Wyoming. Corresponding PV time-height cross-section analysis adds further support, with a descending $\geq 1 \mathrm{PVU}$ isoline over Wyoming (data not shown) through 5-6 June 2012. Forward trajectories from Hybrid Single Particle Trajectory Integrated Trajectory model (HYSPLIT-WEB (internet-based)) also confirm the eastward movement of the system and the descending trajectory from $5 \mathrm{~km}$ at 18:00 UTC on the 5 June 2012 over the offshore and inland vertical profile sites with some ensemble trajectories intersecting with ground level over Wyoming (Draxer and Rolph, 2013).

\section{Conclusions}

The difference in the trace gas composition of the stratosphere compared to the troposphere permits the identification of air masses of stratospheric origin found within the free troposphere occurring during STT. In this paper two STT case studies, sampled over California, were presented: one on 14 May 2012 associated with a cutoff low and one on 5 June 2012 occurring within a tropopause fold during a posttrough, building ridge event.

In each case, a region of enhanced $\mathrm{O}_{3}$, an $\mathrm{O}_{3}$ lamina, was observed and at altitudes as low as $3 \mathrm{~km}$ above sea level. During both events the stratospheric air was characterized by high $\mathrm{O}_{3}$ and low water vapor and $\mathrm{CO}_{2}$ mixing ratios. The observation of decreased $\mathrm{CO}_{2}$ within the stratospheric air mass is consistent with the varying seasonal cycles of $\mathrm{CO}_{2}$ in the troposphere and stratosphere and provides evidence and support for the use of in situ $\mathrm{CO}_{2}$ measurements as an additional method for detecting STT events.

RAQMS $\mathrm{O}_{3}$ analysis and RDF diagnostics provide a largescale context for the interpretation of the airborne measurements. RDF results show that the two STT events had very different air mass histories. The 14 May $2012 \mathrm{O}_{3}$ lamina was associated with a tropopause fold developing from a cutoff low-pressure system that moved into central California from the southwest and experienced efficient large-scale mixing during the previous 6 days. As a result, the $\mathrm{O}_{3}$ lamina was composed of air with histories that extended over a wide 
longitudinal range with considerable initial variability in $\mathrm{O}_{3}$ mixing ratios. In contrast, the back trajectories from the 5 June 2012 tropopause fold showed its history from within the core of a large, stationary low-pressure system over the Gulf of Alaska, which remained relatively isolated with very little large-scale mixing during the previous 6 days. Comparisons between the in situ $\mathrm{O}_{3}$ and RAQMS RDF and analyzed $\mathrm{O}_{3}$ along the flight track show that the $\mathrm{RDF} \mathrm{O}_{3}$ was able to do a very good job in capturing the high ozone within the 14 May $2012 \mathrm{O}_{3}$ lamina, while the analyzed $\mathrm{O}_{3}$ was not able to maintain the strong vertical gradients that were observed. This was attributed to increasing numerical diffusion as the scale of the STT event approached the model grid scale. Neither the RDF nor analyzed $\mathrm{O}_{3}$ was able to capture the high $\mathrm{O}_{3}$ observed during the 5 June 2012 tropopause fold.

The impact of the two STT events on the $0-9 \mathrm{~km} \mathrm{O}_{3}$ budget has been assessed by comparing the total,measured 0 $9 \mathrm{~km} \mathrm{O}_{3}$ (DU) from each analysis day. The STT event on 14 May 2012, although displaying a smaller $\mathrm{O}_{3}$ maximum mixing ratio, had a greater total $\mathrm{O}_{3}$ DU value in the $0-9 \mathrm{~km}$ layer than the 5 June 2012 STT event. The fine filament structure of the $\mathrm{O}_{3}$ lamina on 5 June 2012 would make it difficult to detect this STT event from $\mathrm{O}_{3}$ column measurements. However, narrow filaments could likely be detected by other remote sensing techniques such as $\mathrm{O}_{3}$ lidar. Given clear sky conditions, $\mathrm{O}_{3}$ lidar measurements provide frequent measurements of $\mathrm{O}_{3}$ profiles over a specific site (if surface-based) providing good temporal coverage but limited spatial coverage. $\mathrm{O}_{3}$ lidar potentially provides complementary data to aircraft measurements, which provide good spatial and vertical coverage but limited temporal coverage. This work highlights the importance of $\mathrm{O}_{3}$ vertical profile measurements in the detection of STT, which in some cases, depending on location and the fine-scale structure of $\mathrm{O}_{3}$ laminae, may be the only way to detect and analyze different occurrences of STT accurately.

Investigations were conducted to assess the potential impacts of these STT events on rural surface $\mathrm{O}_{3}$ monitoring sites. Evidence supporting the influence of stratospheric air masses on monitoring sites was detected, with a particular $\mathrm{O}_{3}$ episode exceeding NAAQS $\mathrm{O}_{3}$ standard measured at South Pass, Wyoming, likely associated with the observed tropopause fold on 5 June 2012. More quantitative support for the influence of stratospheric air masses on surface $\mathrm{O}_{3}$ requires additional airborne measurements and multi-scale, nested modeling approaches. This study has shown that the RAQMS global $\mathrm{O}_{3}$ analyses underestimate the high $\mathrm{O}_{3}$ mixing ratios observed in both STT events. As a result, higher resolution modeling studies using global-scale $\mathrm{O}_{3}$ analyses for lateral boundary conditions likely underestimate the magnitude of the exceedances due to STT. Preliminary comparisons between South Pass, Wyoming, surface $\mathrm{O}_{3}$ observations and predictions from nested RAQMS/WRF-CHEM $8 \mathrm{~km}$ simulations of the June STT event confirm this.
Acknowledgements. The authors gratefully recognize the support and partnership of H211 L. L. C., with particular thanks to K. Ambrose, R. Simone, B. Quiambao, J. Lee, J. McMahon, and R. Fisher. Funding was provided by the NASA Postdoctoral Program (J. T.), San Jose State University Research Foundation (E. Y.), and the Bay Area Environmental Research Institute (M. R.). Funding for instrumentation and aircraft integration is gratefully acknowledged from Ames Research Center Director's funds. Helpful discussions with R. S. Hipskind, P. Hamill, L. Pfister and R. Chatfield are happily acknowledged. Technical contributions from Z. Young, E. Quigley, R. Walker, and A. Trias made this project possible. The views, opinions, and findings contained in this report are those of the author(s) and should not be construed as an official National Oceanic and Atmospheric Administration or US Government position, policy, or decision.

Edited by: H. Wernli

\section{References}

Aoki, S., Nakazawa, T., Machida, T., Sugawara, S., Morimoto, S., Hashida, G., Yamanouchi, T., Kawamura, K., and Honda, H.: Carbon dioxide variations in the stratosphere over Japan, Scandinavia and Antarctica, Tellus B, 55, 178-186, doi:10.1034/j.16000889.2003.00059.x, 2003.

Aumann, H. H. and Miller, C.: Atmospheric Infrared Sounder (AIRS) on the Earth Observing System, SPIE, 2583, 32-343, doi:10.1117/12.228579, 1995.

Boering, K. A., Wofsy, S. C., Daube, B. S., Schneidner, H. R., Loewenstein, M., Podolski, J. R., and Conway, T. J.: Stratospheric mean ages and transport rates from observations of carbon dioxide and nitrous oxide, Science, 22, 1340-1343, doi:10.1126/science.274.5291.1340, 1996.

Bonasoni, P., Evangelisti, F., Bonafe, U., Ravegnani, F., Calzolari, F., Stohl, A., Tositti, L., Tubertini, O., and Colombo, T.: Stratospheric ozone intrusion episodes recorded at Mt. Cimone during the VOTALP project: case studies, Atmos. Environ., 34, 13551365, 2000.

Bourqui, M. S. and Trépanier, P.-Y.: Descent of deep stratospheric intrusions during the IONS August 2006 campaign, J. Geophys. Res., 115, D18301, doi:10.1029/2009JD013183, 2010.

Bowman, K. P., Pan, L. L., Campos, T., and Gao, R.: Observations of fine-scale transport structure in the upper troposphere from the High-performance Instrumented Airborne Platform for Environmental Research, J. Geophys. Res., 112, D18111, doi:10.1029/2007JD008685, 2007.

Chane-Ming, F., Guest, F., and Karloy, D. J.: Gravity waves observed in temperature, wind and ozone data over Macquarie Island, Aust. Meteorol. Mag., 52, 11-21, 2003.

Chung, Y. S. and Dann, T.: Observations of stratospheric ozone at the ground level in Regina, Canada., Atmos. Environ., 19, 157162, doi:10.1016/0004-6981(85)90147-7, 1985.

Cooper, O. R., Stohl, A., Hübber, G., Hsie, E. Y., Parrish, D. D., Tuck, A. F., Kiladis, G. N., Oltmans, S. J., Johnson, B. J., Shapiro, A., Moody, J. L., and Lefohn, A. S.: Direct transport of midlatitude stratospheric ozone into the lower troposphere and marine boundary layer of the tropical Pacific Ocean, J. Geophys. Res., 110, D23310, doi:10.1029/2005JD005783, 2005. 
Cooper, O. R., Oltmans, S. J., Johnson, B. J., Brioude, J., Angevine, W., Trainer, M., Parrish, D. D., Ryerson, T. R., Pollack, I., Cullis, P. D., Ives, M. A., Tarasick, D. W., Al-Saadi, J., and Stajner, I.: Measurement of western U.S. baseline ozone from the surface to the tropopause and assessment of downwind impact regions, J. Geophys. Res., 116, D00V03, doi:10.1029/2011JD016095, 2011.

Danielsen, E. F.: Stratospheric-tropospheric exchange based on radioactivity, ozone and potential vorticity, J. Atmos. Sci., 25, 502518, 1968.

Danielsen, E. F. and Mohnen, V. A.: Project duststorm report: ozone transport, in-situ measurements, and meteorological analysis of tropopause folding, J. Geophys. Res., 82, 5867-5877, doi:10.1029/JC082i037p05867, 1977.

Danielsen, E. F., Hipskind, R. S., Starr, W. L., Vedder, J. F., Gaines, S. E., Klev, D., and Kelly, K. K.: Irreversible transport in the stratosphere by internal waves of short vertical wavelength, J. Geophys. Res., 96, 17433-17452, doi:10.1029/91JD01362, 1991

Draxer, R. R. and Rolph, G. D.: HYSPLIT (HYbrid Single Particle Lagrangian Integrated Trajectory) Model access via NOAA ARL READY website http://www.arl.noaa.gov/HSPLIT.php (last access: 30 September 2013), NOAA Air Resources Laboratory, College Park, MD, 2013.

Ebel, A., Hass, H., Jakobs, H. J., Laube, M., Memmesheimer, M., Oberreuter, A., Geiss, H., and Kuo, Y.-H.: Simulation of ozone intrusion caused by a tropopause fold and cut-off low, Atmos. Environ., 25, 2131-2144, 1991.

Fairlie, T. D., Avery, M. A., Pierce, R. B., Al-Saadi, J., Dibb, J., and Sachse, G.: Impact of multiscale dynamical processes and mixing on the chemical composition of the upper troposphere and lower stratosphere during the Intercontinental Chemical Transport Experiment-North America, J. Geophys. Res., 112, D16S90, doi:10.1029/2006JD007923, 2007.

Fiore, A., Jacob, D. J. Liu, H., Yantosca, R. M., Fairlie, T. D., and Li, Q.: Variability in surface ozone background over the United States: Implications for air quality policy, J. Geophys. Res., 108, 4787, doi:10.1029/2003JD003855, 2003.

Gurk, Ch., Fischer, H., Hoor, P., Lawrence, M. G., Lelieveld, J., and Wernli, H.: Airborne in-situ measurements of vertical, seasonal and latitudinal distributions of carbon dioxide over Europe, Atmos. Chem. Phys., 8, 6395-6403, doi:10.5194/acp-8-6395-2008, 2008.

Haynes, P. H. and McIntyre, M. E.: On the conservation and impermeability theorems for potential vorticity, J. Atmos. Sci., 47, 2021-2031, 1990.

Hocking, W. K., Carey-Smith, T., Tarasick, D. W., Argall, P. S., Strong, K., Rochon, Y., Zawadzki, I., and Taylor, P. A.: Detection of stratospheric ozone intrusions by windprofiler radars, Nature, 450, 281-284, 2007.

Hoor, P., Gurk, C., Brunner, D., Hegglin, M. I., Wernli, H., and Fischer, H.: Seasonality and extent of extratropical TST derived from in-situ CO measurements during SPURT, Atmos. Chem. Phys., 4, 1427-1442, doi:10.5194/acp-4-1427-2004, 2004.

IPCC (Intergovernmental Panel on Climate Change, Climate Change): The Physical Science Basis, Summary for Policymakers - Contribution of Working Group I to the Fourth Assessment Report of the Intergovernmental Panel on Climate Change, Cambridge University Press, New York, 2007.
Kleist, D. T., Parrish, D. F., Derber, J. C., Treadon, R., Wu, W.-S., and Lord, S.: Introduction of the GSI into the NCEP Global Data Assimilation System, Weather Forecast., 24, 1691-1705, 2009.

Lamarque, J.-F. and Hess, P. G.: Cross-tropopause mass exchange and potential vorticity budget in a simulated tropopause folding, J. Atmos. Sci., 51, 2246-2269, 1994.

Langford, A. O., Aikin, K. C., Eubank, C. S., and Williams, E. J.: Stratospheric contribution to high surface ozone in Colorado during springtime, Geophys. Res. Lett., 36, L12801, doi:10.1029/2009GL038367, 2009.

Langford, A. O., Brioude, J., Cooper, O. R., Senff, C. J., Alvarez II, R. J., Hardesty, R. M., Johnson, B. J., and Oltmans, S. J.: Stratospheric influence on surface ozone in the Los Angeles area during late spring and early summer of 2010, J. Geophys. Res., 117, D00V06, doi:10.1029/2011JD016766, 2012.

Lefohn, A. S., Wernli, H., Shadwick, D., Limbach, S., Oltmans, S. J., and Shapiro, M.: The importance of stratospherictropospheric transport in affecting surface $\mathrm{O}_{3}$ mixing ratios in the western United States, Atmos. Environ., 45, 4845-4857, doi:10.1016/j.atmosenv.2011.06.014, 2011.

Lefohn, A. S., Wernli, H., Shadwick, D., Oltmans, S., and Shapiro, M.: Quantifying the importance of stratosphere-troposphere transport on surface ozone concentrations at high- and low- elevation monitoring sites in the United States, Atmos. Environ., 62, 646-656, doi:10.1016/j.atmosenv.2012.09.004, 2012.

Levelt, P. F., van den Oord, G. H. J., Dobber, M. R., Mälkki, A., Visser, H., de Vries, J., Stammes, P., Lundell, J. O. V., and Saari, H.: The Ozone Monitoring Instrument, IEEE T. Geosci. Remote, 44, 1093-1101, doi:10.1109/TGRS.2006.872333, 2006.

Lin, M., Fiore, A. M., Cooper, O. R., Horowitz, L. W., Langford, A. O., Levy II, H., Johnson, B. J., Naik, V., Oltmans, S. J., and Senff, C. J.: Springtime high surface ozone events over the western United States: Quantifying the role of stratospheric intrusions, J. Geophys. Res., 117, D00V22, doi:10.1029/2012JD018151, 2012.

Nakazawa, T., Miyashita, K., Aoki, S., and Tanaka, M.: Temporal and spatial variations of upper troposphere and lower stratospheric carbon dioxide, Tellus B, 43, 106-117, doi:10.1034/j.1600-0889.1991.t01-1-00005.x, 1991.

Pierce, R. B. and Fairlie, T. D. A.: Chaotic advection in the stratosphere: Implications for the dispersal of chemically perturbed air from the polar vortex, J. Geophys. Res., 98, 18589-18595, 1993.

Pierce, R. B., Grose, W. L., Russell III, J. M., and Tuck, A. F.: Evolution of southern hemisphere spring air masses observed by HALOE, Geophys. Res. Lett., 21, 213-216, doi:10.1029/93GL02997, 1994

Pierce, R. B., Schaack, T. K., Al-Saadi, J., Fairlie, T. D., Kittaka, C., Lingenfelser, G., Natarajan, M., Olson, J., Soja, A., Zapotocny, T. H., Lenzen, A., Stobie, J., Johnson, D. R., Avery, M., Sachse, G., Thompson, A., Cohen, R., Dibb, J., Crawford, J., Rault, D., Martin, R., Szykman, J., and Fishman, J.: Chemical data assimilation estimates of continental US ozone and nitrogen budgets during the Intercontinental Chemical Transport Experiment - North America, J. Geophys. Res., 112, D12S21, doi:10.1029/2006JD007722, 2007.

Pierce, R. B., Al-Saadi, J., Kittaka, C., Schaack, T., Lenzen, A., Bowman, K., Szykman, J., Soja, A., Ryerson, T., Thompson, A. M., Bhartia, P., and Morris, G. A.: Impacts of background ozone production on Houston and Dallas, TX Air Quality during 
the TexAQS field mission, J. Geophys. Res., 114, D00F09, doi:10.1029/2008JD011337, 2009.

Plougonven, R., Teitelbaum, H., and Zeitlin, V.: Inertia gavity wave generation by the tropospheric midlatitude jet as given by the Fronts and Atlantic Storn-Track Experiment radio soundings, J. Geophys. Res., 108, 4686, doi:10.1029/2003JD003535, 2003.

Sawa, Y., Machida, T., and Matsueda, H.: Seasonal variations of $\mathrm{CO}_{2}$ near the tropopause observed by commercial aircraft, J. Geophys. Res. 113, D23301, doi:10.1029/2008JD010568, 2008.

Schaack, T. K., Zapotocny, T. H., Lenzen, A. J., and Johnson, D. R.: Global Climate Simulation with the University of Wisconsin Global Hybrid Isentropic Coordinate Model, J. Climate, 17, 2998-2016, 2004.

Skerlak, B., Sprenger, M., and Wernli, H.: A global climatology of stratosphere-troposphere exchange using the ERA-interim dataset from 1979 to 2011, Atmos. Chem. Phys. Discuss., 13, 11537-11595, doi:10.5194/acpd-13-11537-2013, 2013.

Søensen, J. H. and Nielson, N. W.: Intrusion of stratospheric ozone to the free troposphere through tropopause folds - A case study, Phys. Chem. Earth Pt. B, 26, 801-806, 2001.

Sprenger, M. and Wernli, H.: A northern hemispheric climatology of cross-tropopause exchange for the ERA15 time period (19791993), J. Geophys. Res., 108, 8521, doi:10.1029/2002JD002636, 2003.

Sprenger, M., Croci Maspoli, M., and Wernli, H.: Tropopause folds and cross-tropopause exchange: A global investigation based upon ECMWF analyses for the time period March 2000 to Februray 2001, J. Geophys. Res., 108, 8513, doi:10.1029/2002JD002587, 2003.

Stohl, A., Spichtinger-Rakowsky, N., Bonasoni., P., Feldman, H., Memmesheimer, M., Scheel, H. E., Trickl, T., Hübener, S., Ringer, W., and Mandl, M.: The influence of stratospheric intrusions on alpine ozone concentrations, Atmos. Environ., 34, 1323-1354, 2000.

Stohl, A., Bonasoni, P., Cristofanelli, P., Collins, W., Feichter, J., Frank, A., Forster, C., Gerasopoulos, E., Gäggeler, H., James, P., Kentarchos, T., Kromp-Kolb, H., Krüger, B., Land, C., Meloen, J., Papayannis, A., Priller, A., Seibert, P., Sprenger, M., Roelofs, G. J., Scheel, H. E., Schnabel, C., Siegmund, P., Tobler, L., Trickl, T., Wernli, H., Wirth, V., Zanis, P., and Zerefos, C.: Stratosphere-troposphere exchange: A review, and what we have learned from STACCATO, J. Geophys. Res., 108, 8516, doi:10.1029/2002JD002490, 2003.

Sutton, R. T., Maclean, H., Swinbank, R., O’Neill, A., and Taylor, F. W.: High-resolution stratospheric tracer fields estimated from satellite observations using Lagrangian trajectory calculations, J. Atmos. Sci., 51, 2995-3005, 1994.

Thompson, A. M., Stone, J. B., Witte, J. C., Miller, S. K., Pierce, R. B., Chatfield, R. B., Oltmans, S. J., Cooper, O. R., Loucks, A. L., Taubman, B. F., Johnson, B. J., Joseph, E., Kucsera, T. L., Merrill, J. T., Morris, G. A., Hersey, S., Forbes, G., Newchurch, M. J., Schmidlin, F. J., Tarasick, D. W., Thouret, V., and Cammas, J.P.: Intercontinental chemical transport experiment Nzonesonde Network Study (IONS) 2004: 1. Summertime upper troposphere/lower stratosphere ozone over northeastern North America, J. Geophys. Res., 112, D12S12, doi:10.1029/2006JD007441, 2007.
Trickl, T., Bärtsch-Ritter, N., Eisele, H., Furger, M., Mücke, R., Sprenger, M., and Stohl, A.: High-ozone layers in the middle and upper troposphere above Central Europe: potential import from the stratosphere along the subtropical jet stream, Atmos. Chem. Phys., 11, 9343-9366, doi:10.5194/acp-11-9343-2011, 2011.

US Environmental Protection Agency, US EPA: Air quality criteria for ozone and related photochemical oxidants, report EPA/600/R-05/004af, Office of Research and Development, Research Triangle Park, NC. February 2006, US Environmental Protection Agency, 2006.

US Environmental Protection Agency, US EPA: National Ambient Air Quality Standards for Ozone, Federal Register FRL-9102-1, 2938-3052, 2010.

Vaughan, G., Price, J. D., and Howells, A.: Transport into the troposphere in a tropopause fold, Q. J. Roy. Meteor. Soc., 120, 10851103, 1994.

Waters, J. W., Froidevaux, L., Harwood, R. S., Jarnot, R. F., Pickett, H. M., Read, W. G., Siegel, P. H., Cofield, R. E., Filipiak, M. J., Flower, D. A., Holden, J. R., Lau, G. K., Livesey, N. J., Manney, G. L., Pumphrey, H. C., Santee, M. L., Wu, D. L., Cuddy, D. T., Lay, R. R., Loo, M. S., Perun, V. S., Schwartz, M. J., Stek, P. C., Thurstans, R. P., Boyles, M. A., Chandra, K. M., Chavez, M. C., Chen, G.-S., Chudasama, B. V., Dodge, R., Fuller, R. A., Girard, M. A., Jiang, J. H., Jiang, Y., Knosp, B. W., LaBelle, R. C., Lam, J. C., Lee, K. A., Miller, D., Oswald, J. E., Patel, N. C., Pukala, D. M., Quintero, O., Scaff, D. M., Snyder, W. V., Tope, M. C., Wagner, P. A., and Walch, M. J.: The Earth Observing System Microwave Limb Sounder (EOS MLS) on the Aura Satellite, IEEE T. Geosci. Remote, 44, 1075-1092, doi:10.1109/TGRS.2006.873771, 2006.

Worden, H. M., Bowman, K. W., Worden, J. R., Eldering, A., and Beer, R.: Satellite measurements of the clear-sky greenhouse effect from tropospheric ozone, Nat. Geosci., 1, 305-308, 2008.

World Meteorological Organisation, WMO: Atmospheric ozone 1985: Global ozone research and monitoring report, WMO Rep. 16, Geneva, 1986.

Zanis, P., Trickl, T., Stohl, A., Wernli, H., Cooper, O., Zerefos, C., Gaeggeler, H., Schnabel, C., Tobler, L., Kubik, P. W., Priller, A., Scheel, H. E., Kanter, H. J., Cristofanelli, P., Forster, C., James, P., Gerasopoulos, E., Delcloo, A., Papayannis, A., and Claude, H.: Forecast, observation and modelling of a deep stratospheric intrusion event over Europe, Atmos. Chem. Phys., 3, 763-777, doi:10.5194/acp-3-763-2003, 2003.

Zapotocny, T. H., Lenzen, A. J., Johnson, D. R., Reames, F. M., and Schaack, T. K.: A comparison of inert trace constituent transport between the University of Wisconsin isentropic-sigma model and the NCAR Community Climate Model, Mon. Weather Rev., 125, 120-142, 1997. 